\title{
Hubungan Antara Kohesivitas Dan Motivasi Berprestasi Dengan Kemalasan Sosial (Social Loafing) Pada Mahasiswa Jurusan Psikologi Universitas Negeri Padang
}

\author{
Elvia Wulan Heksa Paksi, Ria Okfrima' Rina Mariana \\ Fakultas Psikologi, Universitas Putra Indonesia "YPTK" Padang, Indonesia \\ email: elviawulanheksapaksi@gmail.com riaokfrima@upiyptk.ac.id rinadeded@gmail.com
}

\begin{abstract}
The purpose of this research was to determine (1) ) the relationship between cohesiveness with social loafing on psychology students class 2017 \& 2018 Padang state University, (2)The relationship between achievement motivation and social loafing on psychology students class 2017 \& 2018 Padang State University, (3) The relationship between cohesiveness and achievement motivation with social loafing on psychology students class 2017 \& 2018 Padang State University. The instrument of this research are social loafing scale with validity coefficient from 0,326 up to 0,623 and reliability of 0,876 , cohesiveness scale with coefficient validity from 0,313 up to 0,714 and reliability of 0,773 and achievement motivation scale with coefficient validity from 0,313 up to 0,714 and reliability of 0,893. Data analysis of this research using multiple corelation. The result showed that there was a relationship between cohesiveness and achievement motivation with social loafing on psychology students class 2017 \& 2018 Padang State University, with Fstatistic >Ftable(23,965 > 7,71), p-value = 0,000 ( $p$-value $<0,01), r$ value $=0,287$, and $R$ square value $=0,287$ or $28,7 \%$. Partially, there was a negative and significant relationship between cohesiveness and social loafing, with rxy= $-0,532(p$-value $0,000<0,01)$, and there was a negative and significant relationship between achievement and social loafing, with rxy=-0,032 ( $p$ value 0,000<0,01). The effective contribution of self cohesiveness towards social loafing was $28 \%$, while the contribution of achievement motivation with social loafing was $10 \%$
\end{abstract}

Keyword: social loafing, cohesiveness, achievement motivation

Abstrak

Tujuan dari penelitian ini adalah untuk mengetahui; (1) hubungan antara Kohesivitas dengan kemalasan sosial (social loafing) pada mahasiswa psikologi angkatan 2017 \& 2018 Universitas Negeri Padang, (2) hubungan antara Motivasi Berprestasi dengan Kemalasan Sosial (social loafing) pada mahasiswa psikologi angkatan 2017 \& 2018 Universitas Negeri Padang, (3) hubungan antara kohesivitas dan motivasi berprestasi dengan kemalasan sosial (social loafing) pada mahasiswa psikologi angkatan 2017 \& 2018 Universitas Negeri Padang. Instrumen penelitian menggunakan skala social loafing koefisien validitas 0,326 sampai dengan 0,623 dan reliabilitas 0,876 , skala kohesivitas dengan koefisien validitas 0,313 sampai dengan 0,714 dan reliabilitas 0,773 , dan skala motivasi berprestasi dengan koefisien validitas 0,313 sampai dengan 0,714 dan reliabilitas 0,893. Analisis data penelitian ini menggunakan korelasi berganda. Hasil penelitian menunjukan adanya hubungan antara kohesivitas dan motivasi berprestasi dengan social loafing pada mahasiswa psikologi angkatan 2017 \& 2018 Universitas Negeri Padang, dengan nilai Fhitung $>$ Ftabel $(23,965>7,71)$, $p$-value = 0,000 ( $\mathrm{p}$-value < 0,01), nilai $\mathrm{R}=0,287$, dan nilai $\mathrm{R}$ square $=0,287$ atau $28,7 \%$. Secara parsial terdapat hubungan yang negatif dan signifikan antara kohesivitas dengan social loafing, dengan nilai $r x y=-0,532$ ( $p$-value $0,000<0,01$ ), serta terdapat hubungan yang negatif dan signifikan antara motivasi berprestasi dengan social loafing, dengan nilai $\mathrm{rxy}=-0,032$ (p-value $0,000<0,01)$. Sumbangan efektif kohesivitas terhadap social loafing sebesar $28 \%$ sedangkan sumbangan efektif motivasi berprestasi terhadap social loafing adalah $10 \%$.

Kata kunci : Kemalasan Sosial, Kohesivitas, Motivasi Berprestasi.

\section{Pendahuluan}

Mahasiswa merupakan peserta didik yang terdaftar dan belajar di perguruan tinggi (Kamus Besar Bahasa Indonesia, 2014). Dalam keterlibatannya diperguruan tinggi, mahasiswa dituntut agar dapat bereksplorasi dan bekerja secara nyata untuk memecahkan masalah-masalah dalam kehidupan seharihari serta menghasilkan produk yang nyata. Untuk mencapai hal tersebut, berbagai kegiatan dilakukan oleh mahasiswa seperti belajar di kelas, membaca buku di perpustakaan, membuat makalah, presentasi, diskusi, dan sebagainya. Salah satu kegiatan yang sangat erat kaitannya dengan mahasiswa adalah mengerjakan tugas yang diberikan oleh dosen. Tugas dapat dibedakan menjadi dua, yaitu tugas 
individu dan tugas kelompok (dalam Sutanto dan Simanjuntak, 2015) ${ }^{[1] .}$ Tugas kelompok merupakan tugas yang seringkali diberikan oleh dosen kepada mahasiswa. Bolton menyatakan bahwa $72 \%$ tenaga pendidik di universitas menjadikan tugas kelompok sebagai bagian dari proses belajar mengajar. Hal ini disebabkan karena adanya rasa percaya bahwa hasil dari mengerjakan tugas secara berkelompok lebih baik jika dibandingkan dengan hasil bekerja sendirian (dalam Hall dan Buzwell, 2012) ${ }^{[2]}$. Bekerja dalam kelompok adalah kesempatan yang baik bagi pengalaman belajar mahasiswa dalam mengembangkan kemampuan komunikasi dan kemampuan untuk bekerja dalam kelompok (McCorkle, dkk, dalam Hall \& Buzwel, 2012 ${ }^{[2]}$. Namun, bekerja secara bersama dalam kelompok dapat mengurangi motivasi dan usaha individu (Xiangyu,dkk, dalam Dewi, 2017) ${ }^{[3]}$. Menurut Baron dan Byrne (dalam Krisnasari \& Purnomo, 2017) ${ }^{[4]}$ Fenomena ini merujuk pada menurunnya usaha individu ketika berada dalam kelompok dibandingkan ketika individu bekerja secara sendirian. Karau \& Wiliams mengemukakan bahwa pengurangan motivasi dan usaha ketika individu bekerja secara bersama-sama dibandingkan dengan ketika mereka bekerja secara individual di sebut kemalasan sosial (social loafing). Kemalasan Sosial (Social loafing) didefinisikan sebagai pengurangan motivasi dan usaha yang terjadi ketika individu bekerja secara kolektif dalam kelompok dibandingkan ketika individu bekerja secara individual sebagai rekan yang independen. Lebih lanjut, Myers (2012 ${ }^{[5]}$ mendefinisikan Kemalasan Sosial (Social Loafing) sebagai kecenderungan bagi individu untuk mengeluarkan usaha yang lebih sedikit ketika individu mengumpulkan usahanya untuk mencapai suatu tujuan yang sama dibandingkan jika individu secara individual diperhitungkan. Jadi, individu menjadi "malas" ketika berada di dalam kelompok dan cenderung mengurangi atau mengeluarkan usaha yang lebih sedikit ketika berkerja di dalam kelompok dibandingkan jika bekerja secara individual. Adapun aspek-aspek kemalasan sosial (social loafing) menurut Myers yaitu menurunnya motivasi individu untuk terlibat dalam kegiatan kelompok, sikap pasif, pelebaran tanggung jawab, mendompleng pada usaha orang lain (free rider), dan penurunan kesadaran akan evaluasi dari orang lain. Menurut Bluhm (dalam Simms dan Nichols, 2014 ${ }^{[6]}$ mengerjakan tugas secara berkelompok menguntungkan karena dapat mengurangi stres bagi individu. Lebih lanjut, mengerjakan tugas kelompok (dalam tugas yang dianggap berat), individu bisa mengeluarkan usaha yang sedikit dibandingkan jika menyelesaikan tugas sendirian akan mengeluarkan usaha lebih banyak yang membuat munculnya stres bagi individu. Mengerjakan tugas kelompok juga memungkinkan setiap anggota memberikan kontribusinya yang dapat mengoptimalkan hasil akhir dari tugas kelompok tersebut. Mengerjakan tugas secara berkelompok juga membuat pekerjaan yang berat dilakukan secara individual menjadi lebih ringan apabila dikerjakan secara berkelompok. Salah satu penyebab terjadinya kemalasan sosial (social loafing) adalah rendahnya kohesivitas kelompok. Michaelsen, dkk., (dalam Goo, 2011) ${ }^{[7]}$ menyatakan bahwa kohesivitas kelompok merupakan hal yang signifikan dalam pencapaian kerja kelompok. Perilaku kemalasan sosial dapat menjadi sebuah masalah karena dapat menimbulkan kekecewaan pada mahasiswa saat bekerja dalam kelompok (Pang, dkk, dalam Anggreini \& Alfian, 2015) ${ }^{[8]}$. Mahasiswa mengalami konflik ketika mereka bekerja sama dengan pelaku kemalasan sosial dalam kelompok. Selain itu kemalasan sosial memberi dampak buruk yaitu dapat menimbulkan rasa sedih atau bahkan iri karena dengan kinerja yang berbeda menghasilkan nilai yang sama. Hal ini berdampak pada hubungan sosial serta dapat membuat kehilangan motivasi bagi anggota lain. Menurut Carron dan Brawley (dalam Harun dan Mahmood, 2012) ( $^{[9]}$ kohesivitas kelompok adalah proses dinamis yang tercermin dalam kecenderungan kelompok untuk tetap bersama dan menjaga kebersamaan dalam mengejar tujuan dasar kelompok dan/atau untuk pemenuhan kebutuhan afektif anggota kelompok. Aspek-aspek kohesivitas kelompok menurut Carron dan Brawley (dalam Harun dan Mahmood, 2012) ${ }^{[9]}$ yaitu integrasi kelompok dalam tugas (group integration-task), integrasi kelompok secara sosial (group integration-social), ketertarikan individu pada kelompok terkait tugas (individual attraction to group-task), dan ketertarikan individu pada kelompok secara sosial (individual attraction to group-social). Dalam mengerjakan tugas kelompok ada beberapa mahasiswa yang malas mengerjakannya karna dalam satu kelompok pasti ada orang yang pintar dan mahasiswa itu takut mengemukakan pendapat atau ide karna takut salah, akibatnya menurunnya motivasi individu untuk terlibat dalam kegiatan kelompok, padahal motivasi berperan penting untuk meningkatkan motivasi berprestasi individu. Motivasi berprestasi yaitu motif yang berkaitan dengan untuk memperoleh prestasi yang baik, memecahkan masalah-masalah yang dihadapi, mengerjakan tugas-tugas secepat mungkin dan sebaik-baiknya. Salah satu aspek seseorang bermotivasi prestasi tinggi yaitu mengambil tanggung jawab atas perbuatan-perbuatannya. Individu dengan motivasi berprestasi tinggi merasa 
dirinya bertanggung jawab terhadap tugas yang dikerjakannya. Seseorang akan berusaha untuk menyelesaikan setiap tugas yang dilakukan dan tidak akan meninggalkannya sebelum menyelesaikan tugasnya begitu juga sebaliknya. Seseorang dengan motivasi berprestasi yang rendah kemungkinan akan meninggalkan tugas yang diberikan sebelum menyelesaikan tugasnya. Seseorang yang kurang bertanggung jawab dalam melakukan tugas kelompok dapat melakukan kemalasan sosial (social loafing). Peneliti melakukan wawancara pada tanggal 11 Maret 2019 dengan mahasiswa psikologi Universitas Negeri Padang diperoleh keterangan bahwa 7 dari 10 orang mahasiswa menunjukkan penurunan keinginan dalam mengerjakan tugas kelompok, hal tersebut ditunjukkan dari jawaban mahasiswa yang mengatakan bahwa mereka lebih suka mengerjakan tugas secara individu karena bisa dikerjakan kapanpun mahasiswa mau dan juga lebih mudah memahami tugas apa yang seharusnya mahasiswa kerjakan. Mahasiswa juga mengatakan bahwa mereka merasa mengerjakan tugas kelompok menjadi beban yang lebih berat daripada tugas individu sehingga menimbulkan rasa malas untuk mengerjakan tugas tersebut. Mahasiswa juga mengatakan bahwa mereka merasa telah cukup memberikan kontribusinya hanya dengan mengerjakan bagian tugasnya saja. Mahasiswa tersebut juga mengatakan bahwa mereka lebih suka mengambil bagian yang lebih sedikit atau lebih mudah saat pembagian tugas dalam kelompok. Mahasiswa mengatakan bahwa jika saat mengerjakan tugas kelompok timbulnya rasa malas lebih besar. Biasanya dirinya dan teman-teman akan terlihat rajin apabila ada penilaian secara langsung dari dosen atau apabila tugas kelompok tersebut dikerjakan didalam kelas, hal tersebut menunjukkan adanya kemalasan sosial (sosial loafing) dalam mengerjakan tugas kelompok. Mahasiswa malas mengerjakan tugas kelompok karena dalam mengerjakan kelompok hanya beberapa orang yang akan mengerjakannya dan yang lainnya sibuk dengan urusannya, ada yang sibuk main handphone dan ada juga yang tidak hadir dalam mengerjakan tugas kelompok. Dalam organisasi mahasiswa tidak mau mengikuti rapat karena dalam organisasi banyak yang tidak akrab dan dalam organisasi tersebut memiliki kelompok-kelompok tertentu atau geng, karena hal tersebut malas mahasiswa lain untuk mengikuti rapat. Penelitian tentang kohesivitas pernah dilakukan oleh Eclisia Selfi Dian Krisnasari dan Jusuf Tjahjo Purnomo (2017) ${ }^{[4]}$ dengan judul Hubungan Antara Kohesivitas dengan Social Loafing Pada Mahasiswa Fakultas Psikologi Universitas Kristen Satya Wacana Salatiga Jawa Tengah. Penelitian lain dilakukan oleh Salamiah Sari Dewi (2017) ${ }^{[3]}$ dengan judul Hubungan Motivasi Berprestasi dengan Social Loafing Pada Mahasiswa Psikologi Universitas Medan Area. Penelitian lainnya dilakukan oleh Kartika Wulandari (2017) ${ }^{[10]}$ dengan judul Hubungan antara Kohohesivitas Kelompok dan Motivasi Berprestasi Dengan Kemalasan Sosial Pada Mahasiswa A Semester V Universitas Islam Sultan Agung Semarang.

\subsection{Kemalasan Sosial (Social Loafing)}

Myers (2012) ${ }^{[23]}$ kemalasan sosial (social loafing) adalah kecenderungan bagi orang -orang untuk mengeluarkan usaha yang lebih sedikit ketika mereka mengumpulkan usaha mereka untuk mencapai suatu tujuan yang sama dibandingkan jika mereka secara individual diperhitungkan.

\subsection{Aspek-aspek Kemalasan Sosial (Sosial Loafing)}

Menurut Myers (dalam Harmaini dkk, 2016 ${ }^{[11]}$ terdapat lima aspek yang membentuk kemalasan sosial (social loafing), yaitu: a) Menurun motivasi individu untuk terlibat dalam kegiatan kelompok b) sikap pasif c) pelebaran tanggung jawab d) free rider e) penurunan kesadaran

\subsection{Kohesivitas}

Forsyth (dalam Harmaini dkk, 2016) ${ }^{[11]}$ mengatakan bahwa kohesivitas kelompok muncul dari ikatanikatan diantara anggota kelompok. Robbin dan Judge (dalam Harmaini dkk, 2016) ${ }^{[11]}$ mendefinisikan kohesivitas kelompok sebagai tingkat ketertarikan antar anggota kelompok sehingga termotivasi untuk tinggal dalam kelompok.

\subsection{Komponen Kohesivitas}

Forsyth (dalam Harmaini dkk, 2016) ${ }^{[11]}$ mengatakan bahwa kohesivitas terdiri dari empat komponen: a) social cohesion b) task cohesion c) perceive cohesion d) emotional cohesion. 


\subsection{Motivasi Berprestasi}

Menurut Mc Clelland Motivasi berprestasi merupakan sebagai suatu usaha untuk mencapai sukses, yang bertujuan untuk berhasil dalam kompetisi dengan suatu ukuran keunggulan. Ukuran keunggulan ini dapat prestasi orang lain, akan tetapi juga dapat prestasinya sendiri sebelumnya.

\subsection{Karakteristik Motivasi Berprestasi}

Menurut Mc Clelland berpendapat bahwa karakteristik orang yang memiliki motivasi tinggi yaitu sebagai berikut : a) memiliki tingkat tanggung jawab pribadi yang tinggi b) berani mengambil dan memikul resiko c) memiliki tujuan realistic d) memiliki rencana kerja yang menyeluruh dan berjuang untuk tujuan e) memanfaatkan umpan balik yang kongkret dalam semua kegiatan yang dilakukan.

\section{Metode Penelitian}

Jenis penelitian ini adalah kuantitatif korelasional dengan variabel penelitian Menurut Sugiyono $(2014)^{[12]}$ variabel penelitian Kemalasan Sosial (Social Loafing) (Y) dan Variabel Independen, $\left(\mathrm{X}_{1}\right)$ Kohesivitas dan $\left(\mathrm{X}_{2}\right)$. Populasi pada penelitian ini adalah mahasiswa jurusan psikologi angkatan 2017-2018. Teknik pengambilan sampel dalam penelitian ini adalah sampling purposive yaitu teknik penentuan sampel dengan pertimbangan tertentu, yaitu mahasiswa jurusan psikologi fakultas ilmu pendidikan universitas negeri padang yang masih aktif mengikuti perkuliahan. Alat ukur yang digunakan dalam penelitian ini adalah skala kohesivitas, skala motivasi berprestasi dan skala kemalasan sosial (social loafing). Menurut Azwar (2017) ${ }^{[13]}$ skala merupakan perangkat pertanyaan yang disusun untuk mengungkap atribut tertentu melalui respon terhadap pertanyaan tersebut. Skala dalam penelitian ini memiliki format respon dengan empat alternatif jawaban. Skala yang digunakan dalam penelitian ini menggunakan format respon jawaban model Likert, yaitu suatu metode pernyataan sikap yang menggunakan respon subjek sebagai penentu nilai skalanya yang telah dimodifikasi menjadi empat alternatif jawaban dan aitem-aitem dalam skala ini dikelompokkan dalam aitem favorable dan unfavorable. Bentuk skala yang digunakan untuk mengukur intensi prososial dan skala kepuasan pengguna menggunakan empat alternatif jawaban, yaitu SS (Sangat Setuju), S (Setuju), TS (Tidak Setuju), dan STS (Sangat Tidak Setuju). Skala penelitian akan melewati berbagai tahap analisis yaitu uji normalitas digunakan untuk mengetahui apakah populasi data terdistribusi normal atau tidak. Uji normalitas menggunakan uji kolmogorov-Smirnov. Uji linearitas bertujuan untuk mengetahui apakah dua variabel mempunyai hubungan yang linear atau tidak. Dua variabel dikatakan mempunyai hubungan yang linear bila signifikasi (linearty) kurang dari 0,05. Selain itu dilakukan uji Validitas, sejauh mana ketepatan dan kecermatan suatu alat ukur dalam melakukan fungsi ukurnya (Azwar, 2017) ${ }^{[13]}$. Suatu item dapat dianggap memiliki daya diskriminasi yang memuaskan jika berkorelasi signifikan terhadap skor total atau jika melakukan penilaian langsung terhadap koefisien korelasi bisa digunakan batas nilai berkriteria $\mathrm{r}_{x y} \geq 0,3$ (Priyatno, 2013) ${ }^{[14]}$. Data skala dikatakan memiliki daya beda tinggi jika koefisien korelasi lebih besar atau sama dengan $0,3\left(r_{x y} \geq 0,3\right)$ dan sebaliknya aitem skala dikatakan gugur jika koefisien korelasi lebih kecil dari $0,3\left(\mathrm{r}_{\mathrm{xy}} \geq 0,3\right)$.

\section{Hasil dan Pembahasan}

Peneliti menyebarkan 122 skala kohesivitas, skala motivasi berprestasi dan skala Kemalasan Sosial (Social Loafing) dan meminta kesediaan kepada mahasiswa jurusan psikologi angkatan 2017-2018 tersebut untuk mengisi skala kemudian menjelaskan cara pengisian skala dengan cara memberikan skala secara langsung kepada mahasiswa jurusan psikologi angkatan 2017-2018 Universitas Negeri Padang. Sebelum pengisian skala dilakukan, peneliti terlebih dahulu memberitahukan petunjuk pengisian dengan singkat dan jelas.

\subsection{Hasil}

Koefisien Validitas skala kemalasan sosial (social loafing) dengan nilai corrected item-total correlation berkisar antara 0,326 sampai dengan 0,623, dengan reabilitas 0,876, validitas skala kohesivitas dengan nilai corrected item-total correlation berkisar antara 0,313 sampai dengan 0,714, 
dengan reabilitas 0,773 , validitas skala motivasi berprestasi dengan nilai corrected item-total correlation berkisar antara0,313 sampai 0,714, dengan reabilitas 0,893.

Uji normalitas dalam penelitian ini menggunakan uji Kolmogorov-Smirnov. Priyatno (2013) $)^{[14]}$ menyatakan bahwa data yang dinyatakan berdistribusi normal jika signifikansi (p) lebih besar dari 0,05. Berdasarkan hasil pengolahan data dengan menggunakan program IBM SPSS 21.0, maka diperoleh hasil sebagai berikut :

Tabel 1. Uji Normalitas Skala Kohesivitas, Motivasi Berprestasi dan Kemalasan Sosial (Social Loafing)

\begin{tabular}{ccccc}
\hline Variabel & N & KSZ & P & Sebaran \\
\hline Kohesivitas & 122 & 0,824 & 0,505 & Normal \\
\hline Motivasi Berprestasi & 122 & 1,123 & 0,160 & Normal \\
\hline Kemalasan Sosial & 122 & 0,721 & 0,676 & Normal \\
\hline
\end{tabular}

Nilai signifikansi pada skala Kohesivitas sebesar $\mathrm{p}=0,505$ dengan $\mathrm{KSZ}=0,824$ hasil tersebut menunjukan bahwa nilai $\mathrm{p}>0,05$, artinya sebaran skala Kohesivitas terdistribusi secara normal, sedangkan untuk skala Motivasi Berprestasi diperoleh nilai signifikansi sebesar $p=0,160$ dengan $\mathrm{KSZ}=1,123$ hasil tersebut menunjukan bahwa nilai $\mathrm{p}>0,05$, artinya sebaran terdistribusi secara normal. Untuk skala Kemalasan Sosial diperoleh nilai signifikan sebesar $\mathrm{p}=0,676$ dengan $\mathrm{KSZ}=$ 0,721 hasil tersebut menunjukan bahwa nilai $\mathrm{p}>0,05$, artinya sebaran terdistribusi secara normal. Selanjutnya uji linearitas dapat dilihat pada tabel 2 berikut:

Tabel 2. Uji Linieritas skala Kohesivitas dan Social Loafing

\begin{tabular}{ccccc}
\hline $\mathbf{N}$ & Df & Mean Square & F & Sig \\
\hline $\mathbf{1 2 2}$ & 1 & 3037,241 & 47,853 & 0,000 \\
\hline & Tabel 3. Uji Linieritas skala Motivasi Berprestasi & dan Social Loafing & \\
\hline $\mathbf{N}$ & Df & Mean Square & F & Sig \\
\hline $\mathbf{1 2 2}$ & 1 & 10,720 & 0,114 & 0,000 \\
\hline
\end{tabular}

Berdasarkan tabel diatas, diperoleh nilai $\mathrm{F}=3037,241$ dengan signifikansi sebesar $\mathrm{p}=0,000$ dengan ketentuan $(\mathrm{p}<0,05)$, artinya varians pada skala kohesivitas dan social loafing tergolong linier. Berdasarkan tabel diatas, di peroleh nilai $\mathrm{F}=10,720$ dengan signifikan sebesar $\mathrm{p}=0,000$ dengan ketentuan ( $\mathrm{p}<0,05)$, artinya varians pada skala motivasi berprestasi dan social loafing tergolong linier.

Tabel 4. Hasil Uji Korelasi Antara Kohesivitas dan Motivasi Berprestasi dengan Kemalasan sosial (social loafing)

\begin{tabular}{ccccc}
\hline $\mathbf{P}$ & $(\boldsymbol{\alpha})$ & Nilai Korelasi $(\mathbf{r})$ & R square & Kesimpulan \\
\hline 0,000 & 0.01 & $-0,536$ & 0,283 & $\begin{array}{c}\text { sig (2-tailed) } 0,000<0,01 \text { level of } \\
\text { significant }(\alpha), \text { berarti hipotesis } \\
\text { diterima. }\end{array}$ \\
\hline
\end{tabular}

Berdasarkan tabel di atas, maka diperoleh koefisien korelasi antara variabel Kohesivitas dan Motivasi Berprestasi dengan Kemalasan Sosial (Social Loafing) yaitu sebesar $\mathrm{r}=-0,536$ dengan taraf signifikansi $\mathrm{p}=0,000$. Hal ini menunjukkan adanya korelasi yang kuat dan berarah negatif antara ketiga variabel tersebut, yang artinya jika rendah Kohesivitas dan Motivasi Berprestasi, maka tinggi Kemalasan Sosial (Social Loafing), sebaliknya jika tinggi Kohesivitas dan Motivasi Berprestasi, maka semakin rendah Kemalasan Sosial (Social Loafing). Hal ini diperkuat dengan hasil uji signifikansi dengan bantuan IBM SPSS versi 21.0, didapatkan $\mathrm{p}=0,000<0,01$ level of significant $(\alpha)$, artinya hipotesis diterima, bahwa terdapat hubungan antara Kohesivitas dan Motivasi Berprestasi dengan Kemalasan Sosial (Social Loafing) pada mahasiswa jurusan psikologi Universitas Negeri Padang.

Tabel 5. Descriptive Statistic

\begin{tabular}{cccccc}
\hline Variabel & N & Mean & Std. Deviation & Minimum & Maximum \\
\hline Kohesivitas & 122 & 70,28 & 6,466 & 56 & 88 \\
\hline Motivasi Berprestasi & 122 & 74,65 & 6,609 & 60 & 88 \\
\hline Kemalasan sosial & 122 & 57,70 & 9,413 & 34 & 78 \\
\hline
\end{tabular}


Berdasarkan nilai mean empirik, maka dapat dilakukan pengelompokkan yang mengacu pada kriteria pengkategorisasian dengan tujuan menempatkan individu kedalam kelompok-kelompok yang terpisah secara berjenjang menurut suatu kontinum berdasarkan atribut yang diukur (Azwar, 2017) ${ }^{[13]}$ berdasarkan norma kategorisasi, diperoleh kategorisasi subjek penelitian pada variabel, Prososial dan Kepuasan Pengguna sebagai berikut :

Tabel 5. Kategori Prososial dan Kepuasan Pengguna

\begin{tabular}{ccccc}
\hline Variabel & Skor & Jumlah & Persentase (\%) & Kategori \\
\hline \multirow{2}{*}{ Kohesivitas } & $56-63$ & 17 & $14 \%$ & Rendah \\
\cline { 2 - 4 } & $64-75$ & 82 & $67 \%$ & Sedang \\
\cline { 2 - 4 } & $76-88$ & 23 & $19 \%$ & Tinggi \\
\cline { 2 - 4 } Motivasi Berprestasi & $60-67$ & 16 & $13 \%$ & Rendah \\
\cline { 2 - 4 } & $68-80$ & 81 & $66 \%$ & Sedang \\
\cline { 2 - 4 } & $81-88$ & 25 & $20 \%$ & Tinggi \\
\hline \multirow{3}{*}{ Social Loafing } & $34-47$ & 20 & $16 \%$ & Rendah \\
\cline { 2 - 4 } & $48-66$ & 84 & $69 \%$ & Sedang \\
\cline { 2 - 4 } & $67-78$ & 18 & $15 \%$ & Tinggi \\
\hline
\end{tabular}

Berdasarkan tabel di atas, maka dapat diperoleh gambaran bahwa sebesar $14 \%$ atau 17 orang dikategorikan memiliki Kohesivitas yang rendah, sebesar 67\% atau 82 mahasiswa yang sedang, sebesar $19 \%$ atau 23 mahasiswa dikategorikan memiliki intensi kohesivitas yang tinggi sedangkan untuk variabel motivasi berprestasi diperoleh gambaran bahwa sebesar 13\% atau 16 mahasiswa psikologi memiliki motivasi berprestasi yang rendah, sebesar $66 \%$ atau 81 mahasiswa memiliki motivasi berprestasi yang sedang dan sebesar $20 \%$ atau 25 mahasiswa psikologi memiliki motivasi berprestasi yang tinggi.variabel social loafing diperoleh gambaran bahwa sebesar $16 \%$ atau 20 mahasiswa psikologi memiliki social loafing yang rendah, sebesar $69 \%$ atau 84 mahasiswa psikologi memiliki social loafing yang sedang, sebesar 15\% atau 18 mahasiswa psikologi memiliki social loafing yang tinggi. Besar sumbangan variabel kohesivitas dan motivasi berprestasi terhadap variabel kemalasan sosial (social loafing) dapat ditentukan dengan menggunakan rumus koefisien determinan. Koefisien determinan adalah kuadrat dari koefisien korelasi yang dikali dengan $100 \%$. Adapun besar sumbangan efektif ( $R$ square) dari variabel kohesivitas dan motivasi berprestasi terhadap kemalasan sosial adalah sebesar $28 \%$ artinya kohesivitas dan motivasi berprestasi memiliki sumbangan sebesar $28 \%$ terhadap kemalasan sosial sedangkan $72 \%$ dipengaruhi oleh faktor lain seperti tingkat individu meliputi ketergantungan tugas, keterlibatan tugas, keadilan distributive, dan keadilan procedur.

\subsection{Pembahasan}

Penelitian ini bertujuan untuk mengetahui hubungan antara kohesivitas dan motivasi berprestasi dengan kemalasan sosial (social loafing) pada mahasiswa jurusan psikologi Universitas Negeri Padang. Berdasarkan uji hipotesis yang dilakukan menunjukan bahwa terdapat hubungan yang signifikan antara kohesivitas dan motivasi berprestasi dengan kemalasan sosial (social loafing) pada mahasiswa jurusana psikologi Universitas Negeri Padang yang ditunjukan oleh angka koefisien korelasi $r_{x y}=-0,532$ dengan tingkat signifikan korelasi $p=0,000$. Nilai yang positif pada koefisien korelasi menunjukan hubungan antara kohesivitas dan motivasi berprestasi dengan kemalasan sosial (social loafing) pada mahasiswa jurusan psikologi Universitas Negeri Padang, artinya bahwa rendah kohesivitas dan motivasi berprestasi maka tinggi kemalasan sosial (social loafing) dan sebaliknya tinggi kohesivitas dan motivasi berprestasi maka rendah kemalasan sosial (social loafing). Hal ini menyatakan bahwa hipotesis diterima. Hal ini sejalan dengan yang telah dikemukan Sarwono (dalam Krisnasari \& Purnomo, 2017) Social Loafing pada Mahasiswa Psikologi angkatan 2017 \& 2018 Universitas Negeri Padang dapat dipengaruhi oleh tingkat Kohesivitas dan Motivasi Berprestasi. Pada penelitian sebelumnya juga pernah dilakukan oleh Kartika Wulandari pada tahun 2017 dengan judul "Hubungan antara Motivasi Berprestasi dan Kohesivitas kelompok dengan Kemalasan Sosial pada Mahasiswa semester V Universitas Islam Sultan Agung Semarang”.Analisis data penelitian ini menggunakan regresi linier berganda. Hasil penelitian menunjukan adanya hubungan antara motivasi berprestasi dan kohesivitas kelompok dengan kemalasan sosial pada Mahasiswa semester V 
Universitas Islam Sultan Agung Semarang, dengan nilai Fhitung $>\mathrm{F}$ tabel $(125,634>3,11)$, p-value $=$ 0,000 , nilai $\mathrm{R}=0,734$ dan nilai Rsquare $=0,6333$. Secara parsial terdapat hubungan yang negatif dan signifikan antara motivasi berprestasi dengan kemalasan sosial

\section{Kesimpulan}

Berdasarkan hasil pengumpulan data dan analisis data yang telah dilakukan oleh peneliti, maka dapat ditarik kesimpulan yang sekaligus merupakan jawaban dari tujuan penelitian adalah sebagai berikut : (1) Terdapat hubungan yang signifikan antara kohesivitas dan motivasi berprestasi dengan kemalasan sosial (social loafing). Hubungan antara ketiga variabel tersebut negatif yang artinya semakin rendah kohesivitas dan motivasi berprestasi maka semakin tinggi kemalasan sosial dan sebaliknya semakin tinggi kohesivitas dan motivasi berprestasi maka semakin rendah kemalasan sosial. Hal ini berarti hipotesis diterima. (2) Adapun besar sumbangan efektif dari variabel kohesivitas dan motivasi berprestasi dengan kemalasan sosial adalah $28 \%$. sedangkan $72 \%$ dipengaruhi oleh faktor lain.

\section{Daftar Rujukan}

[1] Sutanto Stephanie, Simanjuntak Ermindo. 2015. Intensi Social Loafing Pada Tugas Kelompok Ditinjau Dari Adversity Quotient Pada Mahasiswa. Jurnal Experienta. Surabaya : Fakultas Psikologi Unika Widya Mandala. Vol.03, No. 01, 33-45.

[2] Hall, D., \& Buzwell, S. (2012). The problem of free-riding in group projects : Looking beyond social loafing as reason for non-contribution. Active Learning in Higher Education, 14(1), 36-49.

[3] Dewi, Salamiah Sari, 2017. Hubungan antara motivasi berprestasi dengan social loafing pada mahasiswa psikologi Universitas Medan Area. Jurnal Psikologi. Medan : Fakultas Psikologi Medan Area

[4] Krisnasari E.S.D, Purnomo JT. 2017. Hubungan Kohesivitas Dengan Kemalasan Sosial Pada Mahasiswa. Jurnal Psikologi. Salatiga :Fakultas Psikologi Universitas Kristen Satya Wacana. Vol 13 No.1.

[5] Myers, David G. 2012. Psikologi Sosial Edisi Sepuluh Buku Satu. Jakarta: Salemba Humanika.

[6] Simms, A. I. \& Nichols, T. 2014. Social Loafing :A review of the Literature Journal of Management Policy and Practice, 1,58-67.

[7] Goo, A. B. (2011). Team-based Learning and Social Loafingi n Higher Education. University of Tennessee Honors Thesis Project, (5), 1-56.

[8] Anggreini, F dan Alfian, I.N. 2015. Hubungan Antara Kohesivitas Kelompok dengan Social Loafing dalam Pengerjaan Tugas Kelompok Pada Mahasiswa Psikologi. Skripsi. Universitas Airlangga. 4,81-87.

[9] Harun, M. Z. M. B. \& Mahmood, R. B. (2012). The relationship between group cohesiveness and performance: An empirical study of cooperatives movement in Malaysia. In ternational journal of cooperative studies, 1(1), 15-20.

[10] Wulandari, Kartika. 2017. Hubungan Antara Motivasi Berprestasi dan Kohesivitas Dengan Kemalasan Sosial pada mahasiswa A Semester V Universitas Islam Sultan Agung Semarang. Jurnal Psikologi. Semarang.

[11] Harmaini, dkk. 2016. Psikologi Kelompok Integrasi Psikologi dan Islam. Jakarta: Rajawali Pers.

[12] Sugiyono. 2014. Metode Penelitian Kuantitatif, Kualitatif dan R\&D. Bandung: Alfabeta.

[13] Azwar, Saifuddin. 2016. Penyusunan Skala Psikologi. Yogyakarta: Pustaka Belajar.

[14] Priyatno, Duwi. 2013. Mandiri Belajar Analisis Data Dengan SPSS. Yogyakarta: Mediakom. 